\title{
(Auto)biografismo e ditadura hétero-militar em Fluxo-floema
}

\author{
André Luis Mitidieri \\ Elisabete Costa Silva \\ Universidade Estadual de Santa Cruz - UESC
}

Resumo: A partir das propostas teóricas de Roland Barthes e Leonor Arfuch, consideramos o "espaço biográfico" como uma das maneiras através das quais pessoas LGBTQI+ encontram lócus e veículo para expressão. A estilização da escrita (auto)biográfica na literatura de autoria ou temática homoerótica produzida durante a ditadura "hétero-militar" brasileira (1964-1988), conduziu nossa análise de "Fluxo" e "O Unicórnio", narrativas que compõem o livro Fluxo-floema (1970), da escritora brasileira Hilda Hilst. Aprofundamos nossas bases conceituais com pesquisas históricas realizadas por Renan Honório Quinalha e dados constantes no Relatório da Comissão Nacional da Verdade, que nos permitiram relacionar repressão política e opressão às subjetividades. Concluímos que HH se apropriou ironicamente do discurso dominante, ao explorar corpos, viventes e escriturais, de sujeitos homoeroticamente inclinados, a fim de denunciar a violência gerada pelo regime autoritário ao qual parecem referir-se os seus textos aqui investigados.

Palavras-chave: espaço biográfico; homoerotismo; literatura brasileira; Hilda Hilst

Abstract: Based on Roland Barthes' and Leonor Arfuch's theoretical proposals, we will consider "biographical
space" as one of the ways which LGBTQI+ people find locus and vehicle for their expression. The stylization of
(auto)biographical writing in authorship or thematic homoerotic literature, produced during Brazilian
"heterosexual-military" dictatorship (1964-1988), guided our analysis of "Fluxo" and "O Unicórnio", stories
that compose the book Fluxo-floema (1970), by the Brazilian writer Hilda Hilst. Our conceptual bases are
N.. 39 - 12/ 2018 | 221-240 - ISSN 2183-2242 | http:/dx.doi.org/10.21747/21832242/litcomp39a14 221
INSTITUTO DE LITERATURA COMPARADA MARGARIDA LOSA | WWW.ILCML.COM 
increased with the historical research made by Renan Honório Quinalha and data contained in the National Truth Commission Report, that allowed us to relate political oppression and repression to subjectivities. We conclude that Hilda Hilst has ironically appropriated the dominant discourse itself in order to explore bodies, living and scriptural, of homoerotically bent subjects, to denounce the violence generated by the dictatorial government to which her texts here explored seem to refer.

Keywords: biographical space; homoeroticism; Brazilian literature; Hilda Hilst

Práticas discursivas tidas como extrínsecas à literatura, como a cultura de massa e as (auto)biografias, representam marcas vinculadas à democratização dos discursos, e bastante pronunciadas quando se trata de expressões realizadas por pessoas LGBTQI+ ${ }^{1}$ ou a seu respeito. No conjunto teórico-crítico acerca da escrita (auto)biográfica, proposições sobre o tema, apresentadas por Philippe Lejeune, Roland Barthes, Jacques Derrida, Michel Foucault e Paul Ricoeur, somam-se a pesquisas mais recentemente levadas a termo por Leonor Arfuch (2002), Judith Butler (2017), Diana Klinger (2007), François Dosse (2007) e José Amícola (2007), na tentativa de se discutir os entrecruzamentos da literatura contemporânea com as formas e os gêneros (auto)biográficos.

Estudos acerca da ficção biográfica requerem o esclarecimento das relações entre a ficção literária e o "espaço biográfico", que consiste em uma

confluência de múltiplas formas, gêneros e horizonte de expectativa - supõe um interessante campo de indagação. Permite a consideração das especificidades respectivas sem perder de vista sua dimensão relacional, sua interatividade temática e pragmática, seus usos nas diferentes esferas da comunicação e da ação. (Arfuch 2010: 58-59)

O campo em destaque integra-se pela autobiografia, a biografia, a epistolografia e a hagiografia; pelo autorretrato, o diário íntimo e o memorial descritivo; pelas confissões, consolações, histórias de vida e memórias; por narrativas ficcionais autobiográficas, 
biográficas e memorialísticas; por textos epistolares, ensaísticos e híbridos (romances de modulação autobiográfica, roman-fleuve ou romance de formação) etc. Fazem ainda parte de tal enfeixamento as teorizações acerca dos gêneros instituídos e das espécies antecessoras. Consideramos especialmente a interpenetração dos domínios (auto)biográficos com a narrativa literária ficcional e o importante papel daqueles na configuração da prosa literária, a partir da reflexão básica de Mikhail Bakhtin, segundo a qual alguns gêneros narrativos "exercem um papel estrutural muito importante nos romances, e às vezes chegam a determinar a estrutura do conjunto, criando variantes particulares do gênero romanesco. São eles: a confissão, o diário, o relato de viagens, a biografia, as cartas e alguns outros gêneros" (Bakhtin 2002: 24).

Para apreciações que oferecem maior centralidade às formas e gêneros (auto)biográficos, elegemos um ponto primordial nos estudos começados durante a década de 1970 por Philippe Lejeune e outro ponto, nos desdobramentos críticos desse pensamento, realizados por Leonor Arfuch nos anos 2000. No entanto, as pesquisas de Lejeune (2008) orbitam em torno da autobiografia, enquanto gênero fixado no século XVIII, e se fazem marcar por orientação pragmática, rasurada pelo trabalho de Arfuch (2010), com base fundamental na reflexão bakhtniana, quando sublinha:

os acentos éticos que há muito tempo acompanham o trabalho da narração, sobretudo na ancoragem singular da "boa vida" aristotélica - "com e por outro dentro de instituições justas" - esse caráter valorativo intrínseco que faz com que nenhuma peripécia transcorra num universo neutral e atemporal, sem relação com a experiência humana. É essa orientação ética, que não precisa de nenhuma explicitação normativa, que vai além de uma intencionalidade, que insiste, talvez com maior ênfase, nas narrativas de nosso espaço biográfico, indissociável da posição enunciativa particular, dessa sinalização espaciotemporal e afetiva que dá sentido ao acontecimento de uma história. (Arfuch 2010: 120)

A pesquisadora argentina recorre às indagações de Joan Scott (1996: 387) sobre os modos como são produzidas socialmente as concepções de si e as identidades, a fim de não naturalizarmos "categorias como homem, mulher, negro, branco, heterossexual, homossexual, tratando-as como características desses indivíduos". Nesse caso, segundo 
Arfuch (2010), a estudiosa feminista remete à concepção de Teresa de Lauretis (1992) sobre a experiência resultante da ideologia, num processo de construção da subjetividade por intermédio de várias relações sócio-históricas, que acabariam por investir os sujeitos de autonomia e confiabilidade no conhecimento originado de toda uma teia enredada nas determinações e configurações materiais do mundo circundante.

No entanto, De Lauretis (1992) não deixa de admitir possibilidades de reversão dessa lógica "natural", através de um processo de autoconsciência:

\footnotetext{
Sua aposta, que visualiza a possibilidade de ação política da mulher para reverter a marca "dada" de sua desigualdade, é pensável em geral para toda ideia de identidade como "herança" e "fixação". No âmbito do paradigma bakhtiniano, por outro lado, a experiência é eminentemente social, dialógica, e poderíamos associar a possibilidade de sua transformação à capacidade de autocriação e de mudança acarretada sempre pelos gêneros discursivos, cujos diversos estilos podem aportar elementos revulvisos à cultura de uma época. (Arfuch 2010: 119)
}

Pensando em expectativas de impacto provocativo à ordem social, e na contracorrente de princípios estéticos amparados no substrato iluminista da academia brasileira, propomos olhares críticos capazes de articular diálogos entre expressões literárias e discursos políticos, culturais e sociais, como é o caso do espaço biográfico. Tal perspectiva motiva revisões aos princípios dos estudos literários nacionais, fundamentalmente, aqueles que encaram notações culturais e literárias não canonizadas como "manifestações", produtos de baixo nível, subproduto literário etc. Ao contestá-los, temos em mente a urgência de nos mantermos vigilantes quanto às demandas minoritárias pelo reconhecimento das próprias enunciações marginais ao discurso oficial.

Rever estruturas de manutenção desse discurso e trazer à baila as vozes das próprias margens como produtoras de expressões particulares implica reconhecer subjetividades capazes de constituírem poéticas e políticas resultantes e produtoras de sujeitos empoderados no discurso e na agência. De tal forma, dicções antes interditadas reclamam existência, propõem táticas de subversão dos mecanismos que as relegaram ao silêncio, permitindo-nos compreender representações literárias e culturais de sujeitos e histórias não sintonizados com os centros de poder. 
Nos encalços do percurso traçado desde Leonor Arfuch (2002) a José Amícola (2007), o "espaço biográfico" é visto como uma espacialização onde confluem "formas dissimilares, suscetíveis de serem consideradas numa interdiscursividade sintomática, por si só significativa, mas sem renunciar a uma temporalização, a uma busca de heranças e genealogias, a postular relações de presença e ausência" (Arfuch 2010: 22) através das quais as pessoas, neste caso particular, representativas da diversidade sexual e de gênero, possam encontrar lócus e veículo para expressão de suas subjetividades, experiências, dicções, gostos, gestuais, afetividades etc.

Não se trata, contudo, de reoxigenar o ângulo biográfico da crítica literária e da história da literatura que, do século XIX em diante, tentava explicar a obra pela vida do autor-pessoa, quer dizer, do sujeito empírico que escreve e publica. Tampouco recaímos na “ilusão biográfica”, negada por Pierre Bourdieu (1998), por apontar a determinado horizonte final e estabelecer causalidades nem sempre factíveis. Do contrário, e na contracorrente desse temor, entendemos as potencialidades de desvelamento do sujeito comportadas pela configuração narrativa do gênero biográfico, nas quais o próprio Bourdieu (2003) parece acreditar posteriormente quando organiza a publicação coletiva $A$ miséria do mundo. Entretanto, acautelamo-nos quanto à "falácia biográfica”, identificada por Jacob Stockinger (1978) em certa tendência a interpretar obras literárias como transplantes, para dentro das estórias e suas intrigas, dos acontecimentos supostamente vividos pelo escritor enquanto pessoa física.

Se Foucault (2001) vislumbrou o autor como uma função ou um dispositivo, nunca universalizante, e sujeito a operações complexas, o autor que Roland Barthes assassinou em 1968 parece ser antes de tudo o escritor romântico-positivista, fonte absoluta de todos os sentidos da obra. No entanto, em O prazer do texto (2010), o teórico aponta ao gozo textual, situado em posição entrevista, nas frestas textuais, embora presente no ato da criação e, por isso, desejoso de ser visto pelos leitores, mas divisado apenas em frangalhos. É esse autor disperso, diferente e diferido que ressuscita em todos os trabalhos nos quais Barthes aborda a noção de "biografema", expediente que juntamos às estratégias de "autofiguração" notadas por Amícola (2007), as quais consistem em espécie de ancoragem ou recomposição 
da imagem de si mesmo que o autor se esmera em construir nos meandros de um texto autobiográfico, no qual se enxerta como personagem.

É por esses e outros meios que o espaço biográfico, nele incluídas as estilizações dos seus gêneros e formas, processadas por narrativas literárias, parece mesmo configurar-se como local preferido para enunciação das sexualidades não comportadas pelas previsões heteronormativas. ${ }^{2}$ Importante mencionar que, em contraste com os textos modernistas, nos quais a escrita autobiográfica, segundo Silviano Santiago (2002), buscava recapturar uma experiência pessoal, aliada à do clã no qual se inseria o escritor, há também outro modo, no qual se apresenta

[...] o que consideramos aqui um segundo momento de destaque da escrita de si, nos anos de transição ou da recuperação democrática nos países do Cone Sul que sofreram as ditaduras militares dos anos 70 e 80. Nesse contexto aparecem inúmeros relatos das experiências dos jovens políticos ou dos exilados [...]. (Klinger 2007: 24; grifo da autora)

Para além das narrativas associadas à repressão política e ideológica, textos (auto)biográficos que deem conta, por exemplo, dos vários dispositivos de censura moral e violência simbólica enfrentados por pessoas LGBTTQI constituem desvão talvez frutífero para a revelação das existências e vivências que, assim, transcendem o interesse individual. Entretanto, "não se trata de buscar, aquém, uma inverificável semelhança com uma pessoa real, mas sim de ir além, para verificar, no texto crítico, o tipo de leitura que ela engendra, a crença que produz" (Lejeune 2008: 47). Nesse sentido, as obras literárias calcadas na memória e na narração (auto)biográfica admitem, em suas formas de representação, deliberadas transformações dos acontecimentos que alguma vez teriam ocorrido na vida mesma.

Com efeito, o espaço biográfico contemporâneo é tratado, por Arfuch (2010), como um terreno marcado por gêneros híbridos, que promovem a diluição ou, pelo menos, o turvamento, das fronteiras entre história e literatura. Ao fissurar relatos hegemônicos, sobretudo aqueles vinculados à "heteronormatividade", o conceito habilita-se à exploração de obras literárias que apresentem caráter (auto)biográfico e visibilizem modos através dos quais revisar a história de autoritarismo que o Brasil enfrentou no século XX. Assim, o 
estudo da literatura homoerótica pode servir de trincheira contra incitações discursivas à violência que atinge existências as mais diversas, e tende a se agravar, diante do quadro político anunciado para um futuro bastante próximo, e não menos, indesejável.

No contexto repressor que se desenha, não nos eximimos, porém, de contemplar em nossos horizontes toda uma proliferação discursiva que, seguindo a lógica foucaultiana, se apresenta como perspectiva para interpretações outras dos fatos históricos recentes, através das quais, possamos melhor compreender o quadro atual e promover necessários enfrentamentos às práticas autoritárias que se prenunciam. Nessa paisagem, as subjetividades e as expressões coletivas da contra-hegemonia afrontam a mesma ordem que assinalou, com tintes e requintes de perversidade, nem tão somente a ditadura civilmilitar brasileira, como também os regimes congêneres ocorridos no continente sulamericano entre as décadas de 1960-80.

Nesse caso, narrativas (auto)biográficas demonstram-se constantemente como alternativas de transvio às faces públicas dos acontecimentos, ao se relacionarem com uma possível “cultura homoerótica”, mencionada por José Carlos Barcellos (2006) em Literatura e homoerotismo em questão. À época, a locução que mais tarde perderia terreno para o termo "homocultura" talvez pudesse nomear, mesmo se de forma provisória, toda uma convergência de bens simbólicos elaborados por ou sobre quem dirige o desejo a pessoas do mesmo sexo, mas já não aceita a carga pejorativa implicada na palavra "homossexualismo", razão pela qual, Jurandir Freire Costa pleiteia o conceito de homoerotismo em A inocência e o vício (1992). Para ilustrar a noção defendida nessa obra, o pesquisador se vale do diário íntimo e da biografia do jovem vitoriano Albert Dodd, estudado por Peter Gay; das biografias de Pier Paolo Pasolini, Rainer Werner Fassbinder e Marcel Proust; do romance biográfico de Dominique Fernandez (1985) sobre Pasolini.

Já em $A$ ética $e$ o espelho da cultura, o mesmo autor alude às "confissões pretensamente biográficas", "matéria de literatura subpornográfica" da família Collor (Costa 2000: 89), pouco antes de considerar: "De repente, o nu apareceu na televisão brasileira. Nos filmes, seriados e telenovelas, as relações heterossexuais tornaram-se cada vez mais explícitas e menos sugeridas. Práticas sexuais minoritárias, como o homoerotismo, 
o sadomasoquismo e o incesto deixaram o espaço do segredo e ganharam o da exibição" (ibidem: 107). Numa teia em que se interseccionam escritas e literaturas, história e psicanálise, artes e mídias, pornografia e micropolíticas, a cultura homoerótica converte-se em noção provavelmente eficaz, mas talvez insuficiente quando entra em jogo a diversidade sexual e de gênero, pois não acolhe, dentre outras, as pessoas bissexuais, travestis, transgêneros e intersexuais.

Por isso, valemo-nos do termo "homoerótico" de forma contingencial, com o ambicioso objetivo de mapear e analisar, no âmbito do projeto de pesquisa "Literatura, Espaço Biográfico e Homoerotismo em Contextos Ditatoriais: América do Sul e Portugal”, primeiramente, toda uma produção literária que apresentasse cunho, dicção, estilização ou modalização, ao mesmo tempo, (auto)biográfica e homoerótica, realizada no Brasil entre o anos de 1964 e 1976. Nesse período, grande parte, senão a totalidade dos autores selecionados, é mesmo composta por gueis e, em menor escala, lésbicas. Diversidade um pouco maior, quando contemplada, encontra-se nas personagens ou perspectivas adotadas, sendo que a autoria travesti ou transexual, por exemplo, somente aparecerá muitíssimo mais tarde.

Tratamos então de situar, junto ao ferramental peculiar ao espaço biográfico, o autor captado na textualidade e nas redes por meio das quais a subjetividade interfere nos anseios coletivos, investindo na possibilidade de trincar homogeneizações e reducionismos atribuídos pelo cânone, a partir do momento em que exploramos as suas bordas a fim de suscitarmos agência e intervenção crítica. O quadro analítico inaugura-se com o ano de 1964, por ser quando, como sabido, ocorreu o golpe de Estado responsável por instaurar o período ditatorial cujos mecanismos de controle a sujeitos que se desviassem dos padrões heteronormativos abrangiam anúncios, propagandas produções cinematográficas, televisivas, enfim, representações de qualquer espécie, dentre elas, as literárias.

Sujeitos homoeroticamente inclinados eram tidos como perigosos e contrários ao que se entendia por família, moral e "bons costumes", visão que legitimava a violência física, moral e psicológica - que lhes era desferida. Ainda sob esse viés, o artigo "Golpe contra a sexualidade", publicado por Renan Quinalha (2014) discorre sobre como as 
pessoas LGBTQI+ tornaram-se alvo privilegiado da ditadura brasileira. Uma lista das violações, ainda que incompleta, impressiona:

Perseguição a travestis [...]; censura ao teatro e às artes que simbolizavam de forma aberta as sexualidades dissidentes; homofobia e lesbofobia institucionalizadas; difusão, pela imprensa, do preconceito contra os "desvios", para reforçar a ideia de degeneração dos valores morais e o estereótipo do "inimigo interno"; desarticulação do então nascente movimento LGBT [...], além da ausência de políticas de saúde pública adequadas para tratar das especificidades desses grupos sociais. (Quinalha 2014: s./p.)

Tal discussão é ampliada por Quinalha em sua tese, publicada sob o título Contra a moral e os bons costumes: a política sexual da ditadura brasileira (1964-1988), na qual nomeia esse período autoritário como "hétero-militar", uma vez que o combate às sexualidades desviantes se constituiu em política de Estado, por intermédio de minucioso padrão regulatório. Logo na introdução, o autor considera o peso dos instrumentos regulatórios em regimes marcados por excessiva centralização, como foi o regime ditatorial brasileiro em questão:

É evidente que todos os regimes políticos e formas de governo dispõem, em maior ou menor grau, de normas e instituições para regular as dimensões da vida familiar de seus cidadãos. [...] No entanto, quanto mais fechado e conservador é o regime político, mais há uma tendência em intensificar modos de controle nos espaços públicos e privados. (Quinalha 2017: 19-20)

Com efeito, o estudo "Ditadura e homossexualidades", presente no volume II do Relatório da Comissão Nacional da Verdade (2014), permite notar que a ideologia por detrás da Doutrina de Segurança Nacional de 1964 "continha claramente uma perspectiva homofóbica, que relacionava a homossexualidade às esquerdas e à subversão [...] como parte relevante de uma conspiração comunista mais geral de subverter o Brasil" (Brasil 2014: 301-303). Embora a política de extermínio não fosse explícita, a veiculação de estigmas e imagens negativas acerca das pessoas LGBTQI+, quando não as lançavam à esperada invisibilidade, aravam o terreno para abusos e silenciamentos. 
Foi nessa moldura contextual que Hilda Hilst $(\mathrm{HH})$, já conhecida como poetisa e dramaturga, publicou em 1970 o seu primeiro livro em prosa: Fluxo-floema. Marcada por textos polêmicos e de aguçada criticidade, a escritora rendia-se à ficção e se projetava em múltiplos fluxos, colocando em xeque formas de pensamento e posicionamento políticos então vigentes. Suas narrativas nascem de vozes plurais, que ora se contradizem ora se misturam, trazendo à tona discussões sobre a religião, o tempo, a morte, o desejo, de forma por vezes obscura, caótica e única.

Voltamos nossa análise para a leitura de duas narrativas presentes em Fluxo-floema (Hilst 2003): "Fluxo" e "O Unicórnio". A primeira delas, que dá início ao livro, é protagonizada por Ruiska, um escritor às voltas com o seu processo criativo, uma vez que seus textos já não atendem às expectativas do mercado. A voz que narra e, direta ou indiretamente, o papel do escritor, são postos em questão, aproximando o impasse do protagonista ao da própria Hilda Hilst, bem como à inquietação de outros escritores da época.

Em entrevista a Caio Fernando Abreu, em 1987, HH pontua, sobre suas motivações e orientações éticas para escrever em prosa:

Eu acho que a literatura vem do conflito entre a ordem que você quer e a desordem que você tem. Talvez o vírus da ficção tenha vindo desse acúmulo de desordem. [...] A partir daquela convulsão social dos anos 67, 68 aqui no Brasil, comecei a sentir essa premência de me expressar para o outro, [...] de me ordenar. (Hilst 2013: 148-149)

Ao problematizar a dinâmica característica das transformações acumuladas pelos gêneros discursivos, como infere Arfuch (2010), Hilst acaba também por transpô-la em sua obra. Assim, desestabiliza o papel do escritor e a voz autoral, numa referência aos mecanismos de censura exercidos pela ditadura hétero-militar:

Diversos livros foram proibidos. Alguns sequer chegaram a ser publicados e comercializados. Outros foram impedidos de circular depois de já estarem impressos. Uns, ainda, já estavam editados e postos à venda, mas foram perseguidos e apreendidos, tudo para impedir que as ideias "subversivas" ou "imorais" chegassem ao público. (Quinalha 2017: 129) 
Os censores valiam-se da estratégia de desqualificar publicações de cunho erótico e/ou pornográfico, retirando-lhes qualquer aura de literatura. Criações tidas como obscenas não passavam por seu crivo, uma vez que não eram consideradas arte: funcionariam em prol das degradações à moral e aos bons costumes. Em sua História da sexualidade, Michel Foucault (1988) critica o silenciamento à sexualidade e busca analisá-lo à luz das relações de poder:

É preciso tentar determinar as diferentes maneiras de não dizer, como são atribuídos os que podem e os que não podem falar, que tipo de discurso é autorizado ou que forma de discrição é exigida a uns e outros. Não existe um só, mas muitos silêncios e são parte integrante das estratégias que apoiam e atravessam os discursos. (Foucault 1988: 33-34)

Foucault (1988) propõe que se pense no discurso enquanto lócus dos jogos de poder, dos quais emerge um condicionamento, um ideal, do que deve ser entendido como a verdade. Assim, em cada momento histórico, instituições, leis, proposições científicas e filosóficas são absorvidas e, consequentemente, impostas pela/para a sociedade, definindo a norma. HH burla o sistema ao operar com seus fluxos de consciência e revelar, nas entrelinhas, os conflitos passíveis de modificarem a experiência que, sendo sócio-dialógica, transita pelos entraves e pelas necessidades de uma escrita autocriativa: "se não tá com inspiração vai por mim, pega essa tua folha luminosa e escreve aí no meio da folha aquela palavra às avessas. Uc? Não seja idiota, essa é a primeira possibilidade, invente novas possibilidades em torno do" (Hilst 2003:20-21).

O jogo estabelecido com "uc", aquela palavra às avessas, tem o propósito de driblar proibições a palavras de baixo calão e a escritas que versem sobre sexo, órgãos genitais, ou contenham quaisquer referências a eles. No contexto ao qual a narrativa remete, os escritores necessitavam inventar outras possibilidades, e contrapor-se ao mercado editorial, aderente às banalidades, significava encontrar uma solução para passar despercebido, como o texto em análise também permite observar:

Tenho que escrever o que o homem propõe, ai não sei, aiaiaiai. Pensemos. Começa a descrever a coisa como se fosse uma flauta. Distorce o tubo, cria uma teoria [...]: tubo de dúplice função. Hein? Bem, 
Ruiska, então é melhor assim: tubo abissal, em muitos pequeno, noutros canal. [...] Tubo sagrado. Hein? Porque expele a tua matéria deletéria. (idem: 54-55)

Nesse momento, o narrador-personagem entra em complexo diálogo com a instância que opera como desdobramento de si, da sua posição enunciativa, tentando extrapolar o ato interpretativo a fim de comunicar o que precisa, mas da forma que "o homem propõe". No entanto, não é apenas o mercado editorial que se dispõe contra os escritores:

E VOCÊS DOIS QUEM SÃO? Responde corretinho, Ruiska. Sabem, eu escrevia, e esse aqui sou eu mesmo mas do cone sombrio. PÁRA AÍ. Um escritor, senhores, muito bem, o que escreves? Escrevia, sabem, sobre essa angústia de dentro. PÁRA AÍ. Senhores, eis aqui, um nada, um merda neste tempo de luta, enquanto nos despimos, enquanto caminhamos pelas ruas carregando no peito o grito enorme, enquanto nos matam, sim porque nos matam a cada dia, um merda escreve sobre o que o angustia, e é por causa desses merdas, desses subjetivos do baralho, [...] que nós estamos aqui mas chega, chega, morte à palavra desses anêmicos do século. (ibidem: 66)

As pessoas que participavam de um protesto contra o regime interrogam Ruiska e seu alter ego, o anão. Ao contrário do que se imaginaria, os manifestantes também não se coadunam com a escrita "de dentro", porque a consideram demasiadamente subjetiva, sem correspondência aos anseios daqueles que saíam às ruas. A resposta do escritor mostra que, conforme Arfuch (2010), na escrita de caráter autobiográfico ou em suas estilizações, a interação com a experiência humana nunca se revela neutra, nem foge às circunstâncias do próprio tempo: "Espera um pouco, moço, não sou desses não, quando falo de mim quero falar de ti, nós dois e todos, entende?" (ibidem: 66).

A passagem permite fixar um paralelo com o período histórico referido quando, mesmo nos setores de oposição à ditadura, dos quais se poderia esperar um compromisso com a democracia, a repressão se fazia notar e ainda mais intensificava quando o assunto em pauta fosse a sexualidade:

A "contribuição" do movimento comunista internacional para propagar a homofobia aportou no Brasil na forma de uma heterodoxa combinação com a ideologia católica secular conservadora quanto aos costumes sexuais e com um paradigma bem acentuado do já velho machismo latino-americano. 
Além disso, nos agrupamentos revolucionários brasileiros, estava ainda presente um "ethos de masculinidade revolucionária". Todos esses fatores conjugados colaboraram para decantar uma representação das homossexualidades como "desvio pequeno-burguês", manifestação da "decadência burguesa", comportamento sexual contrário à "moral revolucionária" ou ainda degeneração típica do "desbunde". (Quinalha 2017: 242-243)

Ao que parece, a sexualidade não era tida como uma preocupação de ordem política: sujeitos homoeroticamente inclinados representavam, para a direita, um atentado à família, base da sociedade; para a esquerda, resultariam da decadência burguesa. Para alguns setores, a revolução em marcha teria outros problemas com os quais se preocupar. 0 corpus em estudo provoca esse discurso normativo ao evocar temas tidos por imorais, que deveriam ficar fora de um livro publicável, já que pouco "úteis" às convenções sociais, ao senso moral comum, ou até mesmo ao universo da racionalidade revolucionária.

No trecho a seguir citado de "Fluxo-floema", por exemplo, o anão, personagem ridícula e lasciva, narra com aparente naturalidade, como fora "enrabado" por uma imensa serpente:

Velho Ruiska... encontrei a serpente... era de prata esverdeada e... boa essa goiaba. E enrabou-me. Hein? Pois foi. Fiquei preso no covil e o rabo de prata entrava na minha víscera, estufava, olha, cheguei a dar dez gritos de prazer. Disse para a serpente: obrigada amiguinha pelo prazer, pela alegria de ter o teu rabo na minha caverninha. (Hilst 2003: 60-61)

A personagem demonstra prazer ao ter sua "caverninha" invadida, em possível referência a uma relação sexual homoerótica. Outra possibilidade de interpretação remete a uma modalidade de tortura da época, que consistia em introduzir insetos ou outros animais nas genitálias daqueles que não aparentassem heterossexualidade. Em ambos os casos, é interessante salientar a polemicidade do texto e, mais ainda, refletir sobre as razões pelas quais passou despercebido aos olhos da censura. Talvez isso tivesse acontecido porque a escritora apelou para um teor ora cômico, ora ambíguo, chegando, muitas vezes, a passar a ideia de que difundisse, nas páginas escritas, os discursos que ela própria criticava.

Para melhor exemplificar tal entendimento, sigamos para "O Unicórnio", no qual a 
voz que narra, cujo nome não é revelado, se intercala com uma segunda voz, como em diálogo que, segundo Barthes (1988) é uma das formas por intermédio das quais se desestabiliza a autoria, concebida como fonte originária incontestável. A primeira voz conta, à outra, fragmentos de sua vida, e os relaciona a duas personagens que fizeram parte de seu passado:

Vontade de falar a cada hora daqueles dois irmãos. Isso te dá prazer? Não, nenhum prazer. Eles eram malignos. Ela amava mulheres. [...] Ele amava os homens. A irmã era lésbica e o irmão pederasta? Isso tem importância? Não, não tem, mas parece muita coisa numa estória, numa única estória. (idem: 148149; grifo nosso)

No trecho citado, a narradora questiona a presença de uma lésbica e um "pederasta"3 na mesma estória. Com tal questionamento, a narrativa incorpora mais uma vez o discurso hegemônico, revelando a existência de uma baliza, ainda que simbólica, na representação de determinados sujeitos, nesse caso, na literatura. É preciso salientar que, em momento algum, a narradora se coloca contra esse limite:

Você sabe que o Proust fazia muitas maldades? Não diga. É, eu li que ele enfiava uma agulha nos olhinhos dos ratos, só para se divertir. Mas você acredita mesmo que os seres humanos façam essas coisas somente para se divertir? Olha, o Proust era um pederasta. Pois é, era o Proust. 0 Gide também era um pederasta. Pois é, o Gide. 0 Genet... pois é, é o Genet. Você associa a maldade com a pederastia? $\mathrm{Eu}$ associo a pederastia com um defeito físico e o defeito físico com a maldade. Todas as pessoas com um defeito físico são más. (ibidem: 156-157)

Vozes de um arranjo majoritariamente homofóbico são enunciadas em meio à alusão e à contestação da ideia colocada: “[...] há um lugar onde essa multiplicidade se reúne, e esse lugar não é o autor, como se disse até o presente, é o leitor: o leitor é o espaço mesmo onde se inscrevem, sem que nenhuma se perca, todas as citações de que é feita uma escritura" (Barthes 1988: 70). A noção de "pederastia" enquanto defeito, doença, demonstra que a narradora, e a amiga com quem dialoga, também se corrompem por discursos regulatórias dos corpos, sancionam o amor romântico heterossexual e proíbem quaisquer outras possibilidades: 
A tarefa de escrever é tarefa masculina porque exige demasiado esforço, exige disciplina, tenacidade. [...] É preciso dosar virilidade e compaixão. E se você deixasse a rédea solta para o seu irmão pederasta? Não, nunca, veja bem: se ele não é Proust, nem Gide, nem Genet, há o risco de uma narrativa cheia de amenidades. (Hilst 2003: 175)

Com exceção dos nomes citados, assume-se que o escritor ideal deveria ser homem, heterossexual e, mais do que isso, performar masculinidade, virilidade: nem o irmão pederasta nem a irmã lésbica serviriam para tal ofício. Emerge, então, a voz de uma autoridade que se quer, e se vê, superior, cuja escolha, por parte da instância narrativa, parece uma tentativa de comunicar, como gesto político irônico e contestatório da própria autora, um modus operandi que exclui e rebaixa todos aqueles que não se enquadram nos modelos da heteronormatividade.

Por fim, destacamos a seguinte passagem, na qual o discurso hegemônico já não ressoa. Do contrário, as palavras da personagem "pederasta" parecem evidenciar o outro lado - o daqueles cuja identidade é diariamente silenciada, golpeada:

Os vegetais sentem dor, você sabia? Eu disse isso para o irmão pederasta. Sabe o que ele fez? Ele enterrou o canivete na figueira e enquanto escorria uma gosma clara, ele dizia: existir é sentir dor, existir não é ficar ao sol, imóvel, é morrer e renascer a cada dia, é verter sangue, minha amada irmã [...] A dor é patrimônio nosso, é assim: eu sinto dor e por isso eu existo com esse meu contorno. Eu sinto dor e todos os dias recebo vários golpes que me provocarão infinitas dores. Recebo golpes. Golpeio-me. Atiro golpes. Existir com esse meu contorno é ferir-se, é agredir as múltiplas formas dentro de mim mesmo, é não dar sossego às várias caras que irrompem em mim de manhã à noite. (ibidem: 171-172)

O encontro ao qual se refere o irmão homossexual enuncia um corpo que, tendo consciência do seu existir múltiplo, e da sua inadequação ao mundo em que viver, além de perigoso, é dolorido. Se “[...] a vida nunca faz outra coisa senão imitar o livro, e esse mesmo livro não é mais que um tecido de signos, imitação perdida, infinitamente recuada" (Barthes 1988: 69), mesmo por meio de uma escrita a ser deslindada, a autora não se mostra indiferente à condição humana, diante da dor dos outros, em tempos sombrios para homens e homossexuais. 
Assim como a figura autoral construída textual e extratextualmente por Hilda Hilst, em correspondência transversal à $\mathrm{HH}$, da qual igualmente se dissimula, as narrativas aqui analisadas evidenciam o silenciamento imposto sobre pessoas LGBTQI+ e as arbitrariedades às quais foram submetidas, mas não impedem que o discurso sobre as sexualidades aflore aos borbotões, como pensava Foucault (1988). Embora não apresente problematizações explícitas sobre questões homoeróticas relacionadas à ditadura héteromiitar brasileira, é por meio dos jogos de linguagem e das personagens ambíguas, que "a obscena Senhora H" põe em cena algumas possibilidades de representação da diversidade sexual e de gênero no contexto em vista.

A escritora ora se apropria, ironicamente, e pelas vias ficcionais, do discurso autoritário para produzir desvios à heteronormatividade, ora deixa escapar o que poderíamos chamar de traços (auto)biográficos que frutificam dos próprios anseios. Desse modo, enuncia e denuncia questões de violência simbólica, num período durante o qual o medo e a censura rondavam produções e produtores de arte no Brasil. Em "Fluxo" e "O Unicórnio", ainda que possam não reivindicar ou negar diretamente as imposições hegemônicas e, como tais, as heteronormativas, suas personagens apresentam os impasses e as angústias que a literatura recoloca em fluxo contínuo, tanto lá quanto cá.

$\mathrm{Na}$ atual conjuntura de afronta às liberdades individuais e ao Estado civil de direito, estas leituras evocativas de um passado que deveria restar morto e sepulto animam-nos a prosseguir na pesquisa às vozes dissonantes e aos corpos transviados. Trata-se de urgente compromisso, alçado contra qualquer risco ou perigo. Para sua corporificação, o espaço biográfico "não somente alimentará 'o mito do eu' como exaltação narcisista ou voyeurismo - tonalidades presentes em muitas de suas formas -, mas operará, prioritariamente, como ordem narrativa e orientação ética nessa modelização de hábitos, costumes, sentimentos e práticas, que é constitutiva da ordem social" (Arfuch 2010: 32). 


\section{NOTAS}

1 Utilizamos sigla LGBTQI+, entendendo que, como toda e qualquer materialização da dinamicidade da linguagem, estará, portanto, sujeita a modificações complementares, e a significar, de modo ainda provisório, Lésbicas, Gays, Bissexuais, Travestis, Transgêneros, Queers, Intersexuais, e outras formas sem atual definição ou nomeação fixada.

${ }^{2}$ A heteronormatividade é definida por Michael Warner (1991) como um sistema complexo, que envolve variados ângulos das formas e dispositivos da ordem social, constituindo relações de poder através das quais a sexualidade vem a caber dentro da norma e a ser regulamentada. Do mesmo modo, as relações heterossexuais idealizadas acabam por se institucionalizar e configuram um único modelo "normal" de conduta, tornado praticamente obrigatório, porque supostamente caracterizaria o ser humano de modo inequívoco.

${ }^{3}$ A respeito do termo em destaque - "pederasta" -, compartilhamos das discussões de Jurandir Freire Costa (1992) ao pontuar que o uso da pederastia dos gregos, bem como do termo "homossexualidade", evoca um discurso higienista, responsável por cristalizar, no imaginário cultural, um essencialismo referente à norma imposta. Sob essa ótica, pederastas e homossexuais seriam os "anormais", aqueles que não se encaixam nos ideais de masculinidade e heternormatividade vigentes. Como alternativa a essas nomenclaturas, optamos pela expressão "sujeito homoeroticamente inclinado", considerando o "homoerotismo" como um desejo humano em potencial, uma subjetividade, dentre tantas outras possíveis. 


\section{Bibliografia}

Amícola, José (2007), Autobiografía como autofiguración: Estrategias discursivas del Yo y cuestiones de gênero, Rosario/La Plata, Beatriz Viterbo/CINIG.

Arfuch, Leonor (2002), El espacio biográfico: Dilemas de la subjetividad contemporánea, Buenos Aires, Fondo de Cultura Económica.

-- (2010), O espaço biográfico: Dilemas da subjetividade contemporânea, Trad. de Paloma Vidal, Rio de Janeiro, EdUERJ [2002].

Bakhtin (2002), Questões de literatura e de estética: A teoria do romance, 5. russo por Aurora Fornoni Bernardini et al, São Paulo, Anablume/Hucitec.

Barcellos, José Carlos (2006), Literatura e homoerotismo em questão, Rio de Janeiro, Dialogarts.

Barthes, Roland (2004), A morte do autor, in R. Barthes, $O$ rumor da língua, Trad. de Mário Laranjeira, 2. a ed, São Paulo, Martins Fontes, 57-64 [1968].

- - (2010), O prazer do texto, 5. a ed, São Paulo, Perspectiva.

Bourdieu, Pierre (1988), "A ilusão biográfica", in Janaína Amado/Marieta de Moraes Ferreira (orgs.), Usos e abusos da história oral, Rio de Janeiro, Editora FGV, 183-191 [1986]. Bourdieu, Pierre (Coord.) (2003), A miséria do mundo, Trad. de Mateus S. Soares Azevedo, 5. a ed, Petrópolis, RJ, Vozes [1993].

Brasil, República Federativa do (Governo Federal) (2014), "Ditadura e homossexualidades", in Relatório da Comissão Nacional da Verdade: Textos temáticos, Brasília, CNV. < http://comissaodaverdade.al.sp.gov.br/relatorio/tomo-i/parte-iicap7.html> (último acesso em 23/12/2018).

Butler, Judith (2017), Relatar a si mesmo: Crítica da violência ética, Trad. de Rogério Bettoni, Belo Horizonte, Autêntica [2005].

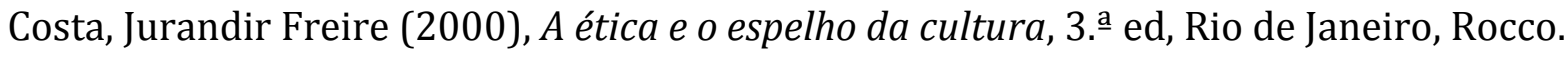


-- (1992), A inocência e o vício: Estudos sobre o homoerotismo, Rio de Janeiro, Relume Dumará.

De Lauretis, Teresa (1992), Alicia y yo, Madrid, Cátedra.

Foucault, Michel (1988), História da sexualidade 2: A vontade de saber, 19. a ed, Trad. de Maria Thereza da Costa Albuqerque e J. A. Guilhon Albuquerque, Rio de Janeiro, Graal.

-- (2001), “O que é um autor?”, in Michel Foucault, Ditos e escritos: Estética - literatura e pintura, música e cinema, vol. III, Rio de Janeiro, Forense Universitária, 264-298 [1983].

Hilst, Hilda (2013), "Deus pode ser um flamejante sorvete de cereja”, in Cristiano Diniz (org.), Fico besta quando me entendem: entrevistas com Hilda Hilst, São Paulo, Globo, 95-102.

-- (2003), Fluxo-floema, São Paulo, Globo.

Klinger, Diana Irene (2007), Escritas de si, escritas do outro: $O$ retorno do autor e a virada etnográfica, Rio de Janeiro, 7Letras.

Lejeune, Philippe (2008), o pacto autobiográfico: De Rousseau à Internet, Trad. de Jovita Noronha, Belo Horizonte, EdUFMG.

Quinalha, Renan Honório (2017), Contra a moral e os bons costumes: A política sexual da ditadura brasileira (1964-1988), Tese (Doutorado em Relações Internacionais) - Instituto de Relações Internacionais, Universidade de São Paulo, São Paulo.

-- (2014), “Golpe contra a sexualidade”, Revista Geni, no. 10, online, <revistageni.org/04/golpe-contra-a-sexualidade> (último acesso em 18/08/2017).

Santiago, Silviano (1992), Nas malhas da letra, Rio de Janeiro, Rocco, 1992.

Scott, Joan (1996), “The Evidence of Experience”, in Terrence J. McDonald, The Historic Turn in the Human Sciences, Ann Arbor, University of Michigan Press, 379-406.

Stockinger, Jacob (1978), "Homotextuality: A Proposal”, in Louie Crew /Ellen Barret (eds.), The Gay Academic, Palm Springs, ETC, 135-151.

Warner, Michael (1993), "Introduction”, in Michael Warner (ed.), Fear of a Queer Planet: Queer Politics and Social Theory, Minneapolis, University of Minnesota Press, VII-XXXI. 
André Luis Mitidieri é graduado em Letras pela URCAMP e em História pela URI-FW, tem mestrado e doutorado em Letras pela PUCRS e pós-doutorado em Estudos Literários pela UFRGS. Ex-docente da graduação em Letras e do PPPGL - Mestrado em Literatura Comparada - da URI-FW (2008-2010), do qual foi sub-coordenador. Atualmente, é professor titular de Literaturas Vernáculas no Curso de Letras, docente efetivo e coordenador do PPGL - Linguagens e Representações - da UESC, onde também dirige o Programa de Extensão "Revisões do Cânone" e lidera o Grupo de Pesquisa (DGP/CNPq) “O Espaço Biográfico no Horizonte da Literatura". É membro da Associação Internacional de Lusitanistas (AIL) e do GT Homocultura e Linguagens, da Associação Nacional de PósGraduação e Pesquisa em Letras e Linguística (ANPOLL).

Elisabete Costa Silva é mestranda no Programa de Pós-Graduação em Letras - Linguagens e Representações - da UESC, onde também concluiu Licenciatura em Letras e faz parte do Grupo de Pesquisa (CNPq) “O Espaço Biográfico no Horizonte da Literatura”. Foi bolseira de Iniciação Científica entre os anos de 2015 e 2018, monitora voluntária do Projeto CriArt em 2014 e do UESC English, em 2017. Atuou como intérprete e tradutora no Yale Alumni Service Corps (YASC), em 2016 e 2017, e como bolseira do subprojeto Letras/Inglês pelo Programa Institucional de Bolsa de Iniciação à Docência (PIBID/CAPES), de 2014 a 2015. 